Stephan Klemme · Hugh StC. O’Neill

\title{
The near-solidus transition from garnet Iherzolite to spinel Iherzolite
}

Received: 9 August 1999 / Accepted: 29 October 1999

\begin{abstract}
The position of the transition from spinel lherzolite to garnet lherzolite in the system $\mathrm{CaO}-\mathrm{MgO}-\mathrm{Al}_{2} \mathrm{O}_{3}-\mathrm{SiO}_{2}$ (CMAS) has been determined experimentally at near-solidus temperatures. In reversed experiments, the transition occurs between 18 and $20 \mathrm{kbar}$ at $1200{ }^{\circ} \mathrm{C}$ and between 26 and $27 \mathrm{kbar}$ at $1500{ }^{\circ} \mathrm{C}$, corresponding to higher pressures than previously envisaged. A position for the transition deeper within the Earth further complicates the explanation of the so-called garnet signatures in the trace element and isotope patterns of mid-ocean ridge basalts. If melting during adiabatic upwelling beneath a mid-ocean ridge begins at the depth required for the stability of garnet in peridotitic compositions, simple melting models predict that the amount of melt produced should be much greater than the observed thickness of the oceanic crust. A partial solution to the apparent conflict might be that (1) the rather simplistic melting models are in error, (2) that melting begins in garnet pyroxenite veins that are believed to be stable at lower pressures than garnet lherzolite or (3) that melting does not involve garnet at all, but it is clinopyroxene causing the trace element patterns observed in basalts erupted at mid-ocean ridges. A second set of reversal experiments were conducted to investigate the solubility of alumina in both orthopyroxenes and clinopyroxenes at the high temperatures near the solidus in the system CMAS. The results are compatible with most previous studies, and may be used as a starting point to calibrate thermodynamic
\end{abstract}

S. Klemme $(\bowtie)^{1} \cdot$ H.StC. O’Neill

Research School of Earth Sciences,

The Australian National University,

Canberra, ACT 0200, Australia

Present address:

${ }^{1}$ Department of Earth Sciences, University of Bristol,

Wills Memorial Building, Queen's Road, Bristol BS8 1RJ, UK

e-mail: stephan.klemme@ bristol.ac.uk

Editorial responsibility: J. Hoefs models for pyroxenes in chemical systems, approximating upper mantle chemistry.

\section{Introduction}

With increasing depths, the aluminous phase in the upper mantle changes from plagioclase to spinel to garnet. The transition from spinel lherzolite (olivine + orthopyroxene + clinopyroxene + spinel $)$ to garnet lherzolite (olivine + orthopyroxene + clinopyroxene + garnet) could potentially influence the characteristics of some kinds of basalts, particularly mid-ocean ridge basalts (MORB), since this transition is thought to occur at about the same depths at which MORB may originate. There is evidence from trace element and isotope geochemistry that MORB are generated in the presence of garnet (Klein and Langmuir 1987; Hirschmann and Stolper 1996). The evidence includes the depletion of heavier rare earth elements relative to lighter rare earth elements (Kay and Gast 1973), depletion in ${ }^{177} \mathrm{Lu} /{ }^{176} \mathrm{Hf}$ (Salters and Hart 1989) and elevated ${ }^{230} \mathrm{Th} /{ }^{238} \mathrm{U}$ ratios (Beattie 1993a, b; LaTourrette et al. 1993). This is generally referred to as the 'garnet signature' in MORB. However, if melting started in the garnet lherzolite stability field, simple melting models (e.g. Klein and Langmuir 1987; McKenzie and Bickle 1988; Iwamori et al. 1995) predict a thickness of the oceanic crust much greater than the average crust at $7 \pm 1 \mathrm{~km}$ inferred from seismological studies (e.g. White et al. 1992). Several possible solutions have been put forward to resolve this apparent conflict, including: (1) reduced melt productivity of upwelling peridotite (Asimov et al. 1995); (2) variations in depth of melting on the top of the melting zone beneath ridges (Shen and Forsyth 1995); or (3) partial melting of small amounts of garnet-bearing assemblages in veins such as garnet pyroxenites or eclogites (among others: Wood 1979; Allègre et al. 1984; Hirschmann and Stolper 1996).

However, such speculation is somewhat premature, in that the position of the spinel lherzolite to garnet 
lherzolite transition in likely upper mantle compositions is surprisingly poorly constrained at near-solidus temperatures by existing experimental data (see Fig. 1 for a summary of previous work).

Several studies have investigated the transition from garnet lherzolite to spinel lherzolite in CMAS at lower temperatures, i.e. from 800 to $1100{ }^{\circ} \mathrm{C}$ (e.g. O'Hara et al. 1971; Jenkins and Newton 1979; O'Neill 1981). However, there is only little and, unfortunately, controversial information available for the high-temperature part of the univariant reaction close to the solidus, the pressure-temperature (P-T) range where mid-ocean ridge magmas are likely to be generated.

The transition from spinel lherzolite to garnet lherzolite is found to be curved (Jenkins and Newton 1979; O'Neill 1981; Gasparik 1984). The curvature with temperature is caused by increasing disorder in $\mathrm{MgAl}_{2} \mathrm{O}_{4}$ spinel with increasing temperature (e.g. Wood et al. 1986) as well as by a large increase in the amounts of alumina dissolved in both orthopyroxene and clinopyroxene with increasing temperature. The curvature cannot be predicted accurately without very accurate thermodynamic models for the order-disorder in spinel, and the solubility of alumina in pyroxenes. Currently available thermodynamic models are not sufficiently well founded for this purpose, especially for aluminous pyroxenes. Hence the position of the transition in P-T space needs to be determined experimentally. Con-

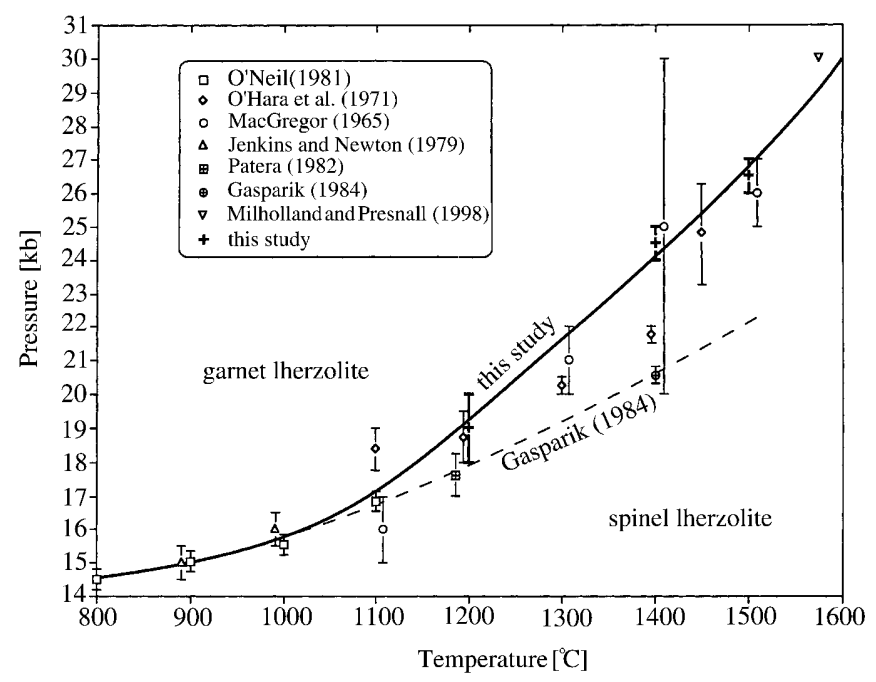

Fig. 1 A compilation of literature data on the transition from spinel lherzolite to garnet lherzolite in the system $\mathrm{CaO}-\mathrm{MgO}-\mathrm{Al}_{2} \mathrm{O}_{3}-\mathrm{SiO}_{2}$. Reversed experiments, analysed with electron microprobe, are from Jenkins and Newton (1979), O'Neill (1981) [corrected for friction, see text for details], Gasparik (1984) and this study. Note that most of the other experiments (within the somewhat large uncertainties) at temperatures above $1200{ }^{\circ} \mathrm{C}$ agree well with the present study; only Gasparik's (1984) experiment is in disagreement. For clarity, all experimental results are represented by average values for the transition and error bars. For example, the $1400{ }^{\circ} \mathrm{C}$ bracket by MacGregor (1965) represents in fact two experiments at 20 and $30 \mathrm{kbar}$ respectively. The higher pressure experiment indicated that the garnet-bearing mineral assemblage grew, while at $20 \mathrm{kbar}$ the spinel-bearing assemblage grew versely, however, determination of the curvature of the transition will then be valuable in constraining thermodynamic models for aluminous pyroxenes. In turn, such information is needed for the further refinement of the ideas of Asimov et al. (1995) concerning melt productivity, e.g. to calculate accurately the entropy change across the transition.

The approach chosen here is to investigate the transition in a chemical system that contains all relevant mantle phases and closely approximates upper mantle composition. The CMAS system is an excellent starting point because its composition represents more than $90 \%$ of the upper mantle's composition and it contains the major mantle minerals olivine, garnet, spinel, orthopyroxene and clinopyroxene. In contrast to experiments in natural, complex compositions, the attainment of equilibrium in simple systems can be rigorously assessed and extraction of thermodynamic data is facilitated.

From a phase equilibrium perspective, the reaction that defines the phase transition from spinel to garnet lherzolite in the system $\mathrm{MgO}-\mathrm{Al}_{2} \mathrm{O}_{3}-\mathrm{SiO}_{2}$ (MAS) may in essence be written as follows:

$$
\begin{array}{cccc}
2 \mathrm{Mg}_{2} \mathrm{Si}_{2} \mathrm{O}_{6} & \underset{\mathrm{MgAl}_{2} \mathrm{O}_{4}}{\mathrm{Mg}_{2}}=\underset{\text { spinel }}{\mathrm{Mg}_{2} \mathrm{SiO}_{4}}+\mathrm{Mg}_{3} \mathrm{Al}_{2} \mathrm{Si}_{3} \mathrm{O}_{12} \\
\text { opx } & \text { olivine } & \text { garnet }
\end{array}
$$

This equilibrium is univariant in the simple MAS system, and remains univariant in the CMAS system if a calcium-containing phase, here clinopyroxene, is present to buffer the chemical potential of $\mathrm{CaO}$.

There are, in principle, two ways to investigate the aforementioned univariant equilibrium. The reaction may be investigated directly by performing reversal experiments with starting material containing both reactants and products of the reaction. Analysis of coexisting phases with X-ray diffraction or electron microprobe shows which phase assemblage grew and which is consumed. However, for situations, such as here, where some of the phases partaking in the reaction are solid solutions of variable composition (orthopyroxene, clinopyroxene and garnet), this standard approach needs extra care to ensure that the compositions of these phases are appropriate for the P-T conditions. Otherwise there is a danger that growth or loss of garnet or spinel may be proceeding metastably. Ideally, therefore, starting materials should be pre-equilibrated in the divariant fields both above and below the anticipated position of the univariant reaction.

A second, somewhat different approach, investigates the behaviour of the isopleths of alumina in the pyroxenes (i.e. curves in P-T space of constant alumina content in orthopyroxene or clinopyroxene). The solubility of alumina in pyroxenes can be described by the following two equations,

$$
\begin{array}{cccc}
\mathrm{MgAl}_{2} \mathrm{O}_{4}+\mathrm{Mg}_{2} \mathrm{Si}_{2} \mathrm{O}_{6}= & \mathrm{MgAl}_{2} \mathrm{SiO}_{6} & +\mathrm{Mg}_{2} \mathrm{SiO}_{4} \\
\text { spinel } & \text { opx } & \text { opx } & \text { olivine } \\
\mathrm{Mg}_{3} \mathrm{Al}_{2} \mathrm{Si}_{3} \mathrm{O}_{12}= & \mathrm{Mg}_{2} \mathrm{Si}_{2} \mathrm{O}_{6} & & \mathrm{MgAl}_{2} \mathrm{SiO}_{6} \\
\text { garnet } & \text { opx } & \text { opx }
\end{array}
$$


The isopleths of alumina in orthopyroxene in equilibrium with garnet (reaction 2) have a positive slope in P-T space, while those in equilibrium with spinel (reaction 1) are almost independent of pressure. The position of the transition from garnet lherzolite to spinel lherzolite can be determined indirectly in P-T space, by investigating where the isopleths intersect.

This study investigates the transition of garnet to spinel lherzolite near the solidus using both approaches. The position of the univariant reaction in CMAS was directly reversed and the solubility of $\mathrm{Al}_{2} \mathrm{O}_{3}$ in pyroxenes near the solidus has been investigated.

Pyroxene compositional variability in the system $\mathrm{CaO}-\mathrm{MgO}-\mathrm{Al}_{2} \mathrm{O}_{3}-\mathrm{SiO}_{2}$

As pyroxene compositions are very sensitive to varying P-T conditions, mineral assemblages containing orthopyroxene and clinopyroxene are widely used as indicators of pressure and temperature in ultramafic rocks such as in orogenic peridotites and mantlederived xenoliths. Pyroxene compositions in the CMAS system may vary considerably in terms of (1) their $\mathrm{Ca} /$ $\mathrm{Mg}$ ratios, (2) their alumina contents and (3) deviations from ideal stoichiometry due to excess $\mathrm{SiO}_{2}$ content (Wood and Henderson 1978; Fockenberg and Schreyer 1997). However, pyroxenes in equilibrium with $\mathrm{Mg}_{2} \mathrm{SiO}_{4}$ (forsterite) appear to have ideal stoichiometry and hence this latter factor will not be discussed further, as all experiments presented here contain forsterite.

The simplest system containing both orthopyroxene and clinopyroxene is the enstatite-diopside join in the system $\mathrm{CaO}-\mathrm{MgO}-\mathrm{SiO}_{2}$ (CMS). The $\mathrm{Ca}-\mathrm{Mg}$ exchange between clinopyroxene and orthopyroxene was first suggested for use for geothermometry by Atlas (1952). Since then, numerous experimental studies have shown that the shape of the miscibility gap between enstatite and diopside is mainly a function of temperature and not of pressure. Phase relations and thermodynamic models of the diopside-enstatite system have been reviewed by Lindsley et al. (1981), Nickel and Brey (1984) and Carlson and Lindsley (1988).

The $\mathrm{Al}_{2} \mathrm{O}_{3}$ exchange between orthopyroxene and garnet (reaction 2) is sensitive to pressure as well as temperature and is commonly used for geothermobarometry (e.g. Wood and Banno 1973; Nickel and Green 1985; Brey et al. 1986). The exchange of $\mathrm{Al}_{2} \mathrm{O}_{3}$ between the orthopyroxene solid solution and spinel (reaction 1), however, is believed to be mainly sensitive to temperature and has found application in the geothermometry of ultramafic rocks (e.g. Gasparik and Newton 1984; Witt-Eickschen and Seck 1991). The alumina content of orthopyroxene coexisting with olivine and spinel has proven to be almost independent of pressure in the MAS system (e.g. Dankwerth and Newton 1978; Gasparik and Newton 1984) as well as in the CMAS system (Obata 1976; Fujii 1977). Gasparik (1984) claimed that the presence of $\mathrm{Ca}$ in the CMAS system appears to reduce the amount of $\mathrm{Al}_{2} \mathrm{O}_{3}$ in orthopyroxene, but this suggestion has not been explicitly incorporated into existing geothermometers and geobarometers.

The presence of minor components such as $\mathrm{Fe}, \mathrm{Cr}$, $\mathrm{Na}$ and $\mathrm{Ca}$ can have a substantial effect on the subsolidus equilibria (e.g. O'Neill 1981). In order to extrapolate results from simple system experiments to the more complex compositions of naturally occurring rocks, thermodynamic models are needed to account for the influence of these minor components. For instance, the influence of chromium on thermodynamics of pyroxenes has previously been underestimated and will be discussed in subsequent papers (see also Klemme 1998; Klemme and O'Neill 1998). However, the solubility of alumina in pyroxenes in the simple system CMAS must be understood first and the present experiments are designed to serve as a starting point for extrapolation into more complex compositions.

\section{Experiments}

Experimental strategy

Reactions in the system CMAS such as the transition from garnet lherzolite to spinel lherzolite are well known for their slow kinetics (O’Neill 1981; Nickel et al. 1985). In order to overcome this problem, lengthy experimental run durations were found to be necessary in our experiments (see Table 2). However, conducting high-pressure experiments at high temperatures for many hours or days leads to another problem: Thermocouples that are used for temperature control in the high-pressure, high-temperature experiments can drift to lower or higher temperatures due to contamination ('thermocouple poisoning'), or due to element migration within the thermocouple material itself. That has been a particular problem in the past with the usual types of thermocouples used in experimental petrology, namely type $\mathrm{S}\left(\mathrm{Pt}-\mathrm{Pt}_{90} \mathrm{Rh}_{10}\right)$.

In order to prevent thermocouple contamination in the lengthy experiments of this study, care was taken to prepare a clean assembly, free of grease or other potential contaminants. Most experiments were conducted with two different thermocouples to guard against possible thermocouple drift due to contamination.

The position of the univariant equilibrium was bracketed in P-T space directly as follows: starting materials containing reactants (i.e. the low-pressure assemblage spinel, forsterite, clinopyroxene, orthopyroxene) as well as products of the reaction (i.e. the highpressure assembly garnet, forsterite, clinopyroxene, orthopyroxene) were run at pressures and temperatures near the position of the univariant curve. Analysis of coexisting phases with X-ray and electron microprobe techniques show which phase assembly is consumed and which phases grow.

A second series of experiments has been conducted at a pressure of $23 \mathrm{kbar}$ and temperatures between 1400 and $1500{ }^{\circ} \mathrm{C}$, again with rather lengthy run times. Experiments were duplicated with two different starting mixtures: one starting material contained pyroxenes with high $\mathrm{Al}_{2} \mathrm{O}_{3}$ content, the other with only half of the $\mathrm{Al}_{2} \mathrm{O}_{3}$ content. Equilibrium was, therefore, reversed in terms of the alumina content of the pyroxenes, i.e. approached from different sides. The information derived from these reversal experiments in the spinel lherzolite stability field may be used in conjunction with literature data to determine the position of alumina isopleths of orthopyroxene in P-T space and, therefore, to indirectly constrain the position of the boundary between garnet lherzolite and spinel lherzolite. 


\section{Starting materials}

All experiments were conducted with mixtures of crystalline starting materials pre-synthesized from oxide mixtures. The choice of crystalline materials in contrast to glass or gel as starting material circumvents nucleation problems of garnets and spinel and also prevents formation of pyroxenes, unrealistically high in $\mathrm{Al}_{2} \mathrm{O}_{3}$, known from unreversed synthesis experiments (cf. Howells and O’Hara 1978; Nickel et al. 1985).

$\mathrm{MgAl}_{2} \mathrm{O}_{4}$ was synthesized at $1200{ }^{\circ} \mathrm{C}$ at atmospheric pressure for $24 \mathrm{~h}$. Forsterite $\left(\mathrm{Mg}_{2} \mathrm{SiO}_{4}\right)$ was prepared at $1050{ }^{\circ} \mathrm{C}$ at atmospheric pressure using a $\mathrm{Li}_{2} \mathrm{WO}_{4}$ flux with a flux/oxide-mix ratio of 4:1 in a Pt-crucible for 6 days. Laser Ablation ICP-MS analysis of the forsterite showed it contained $<300 \mathrm{ppm} \mathrm{Li}$ and $<10 \mathrm{ppm} \mathrm{W}$. Lattice parameters determined with an internal standard of NBS Si are in exact agreement with those obtained for forsterite synthesized directly from pure chemicals. The orthoenstatite $\left(\mathrm{Mg}_{2} \mathrm{Si}_{2} \mathrm{O}_{6}\right)$ was synthesized from the oxides at $1150{ }^{\circ} \mathrm{C}$ and $20 \mathrm{kbar}$ pressure in a graphite capsule. This synthesis experiment was carried out for $24 \mathrm{~h}$. Aluminous clinopyroxenes and orthopyroxenes were synthesized at $1200{ }^{\circ} \mathrm{C}$ and $30 \mathrm{kbar}$ for $12 \mathrm{~h}$. These synthesis runs also contained minor amounts of olivine, whereas no garnet was detected.

All starting materials were checked for composition and homogeneity with the electron microprobe (Ware 1991) and with $\mathrm{X}$-ray diffraction techniques.

Starting materials of the 'direct approach' experiments designed to bracket the position of the garnet-spinel boundary contained synthetic mineral mixtures consisting of all five phases, including minerals on the low-pressure and the high-pressure sides of the reaction. Thus, the starting material contained olivine, clinopyroxene, orthopyroxene, garnet and spinel (Table 1). Mixtures SM 6,9 and 15 are identical.

The 'direct approach' experiments contained synthesized garnets with two different compositions: SM 3 consisted of garnets with $20 \mathrm{~mol} \%$ grossular component and SM 4 garnets with $10 \mathrm{~mol} \%$ grossular component. Five grams of each garnet for the starting mix were synthesized separately at $1400^{\circ} \mathrm{C}, 30 \mathrm{kbar}$ for $24 \mathrm{~h}$ in a large capacity piston-cylinder apparatus at the Research School of Earth Sciences (Australian National University, Canberra).

The starting material of the 'near-solidus solubility' (indirect approach) experiments contained pure forsterite and spinel as well as both orthopyroxenes and clinopyroxenes. Experiments were duplicated: one set of experiments was performed with high-alumina starting material orthopyroxenes and clinopyroxenes (approximately $10 \%$ [wt] $\mathrm{Al}_{2} \mathrm{O}_{3}$ in both pyroxenes) in the starting material (SM 25); a second set of experiments was run with starting material pyroxenes that contained only $\sim 5 \%$ (wt) $\mathrm{Al}_{2} \mathrm{O}_{3}$ (SM 28).

\section{Attainment of equilibrium in the experiments}

There are several ways by which the attainment of equilibrium in the present experiments may be tested. Firstly, low standard deviations in analyses indicate homogeneous compositions, which provides direct evidence for chemical equilibration. Secondly, two

Table 1 Starting materials. SM 6, SM 9 and SM 15 are of identical composition, consisting of $\mathrm{MgAl}_{2} \mathrm{O}_{4}$ (spinel), $\mathrm{Mg}_{2} \mathrm{SiO}_{4}$ (forsterite), SM1 (orthopyroxene and clinopyroxene), and two different garnet different garnet compositions were chosen as starting materials in the 'direct approach' experiments, i.e. garnets with low and high contents of grossular component respectively. Homogeneous garnet compositions throughout the charge were taken as evidence that garnets reached equilibrium in the experiment. Equilibrium in the 'indirect approach' experiments is reversed in terms of the alumina content of the pyroxenes, i.e. the experiments were duplicated with low-alumina and high-alumina start material pyroxene respectively. Although the $\mathrm{Ca} / \mathrm{Mg}$ exchange between clinopyroxene and orthopyroxene has not been reversed, the attainment of equilibrium can be assessed by comparing the present results with thermometric expressions. Table 3 compares experimental temperatures with calculated temperatures using the geothermometer of Nickel et al. (1985).

In order to obtain further evidence for the attainment of equilibrium in the run products we make use of Fick's second law, $h=\sqrt{D \cdot t}$ (Spear 1993), where $D$ is the diffusion coefficient at pressure and temperature, $h$ the radius of the analysed mineral in an experimental charge and $t$ the time. Assuming a diffusion coefficient $D$ for Al diffusion in pyroxene of ca. $10^{-16} \mathrm{~m}^{2} / \mathrm{s}$ needed to homogenize a crystal of $10 \mu \mathrm{m}$ at $1400{ }^{\circ} \mathrm{C}$ (Sautter et al. 1988), the equilibration time can be estimated to be in the order of a few days.

\section{Experimental techniques}

High-pressure, high-temperature experiments were carried out in a conventional piston-cylinder apparatus (Boyd and England 1960) using a $0.5 \mathrm{in}$. diameter assembly. The assembly consists of two inner parts of $\mathrm{MgO}$ ( $66 \%$ density) surrounded by three concentric shells: a graphite heater, a glass tube (Pyrex) and an outermost sleeve of $\mathrm{NaCl}$, pressed to $>95 \%$ of the theoretical density. This low-friction assembly does not require a pressure correction and pressures can therefore be controlled more accurately than in talcPyrex assemblies (Green et al. 1966). High temperatures and long run durations should also ensure that any initial friction, if present, decays (Bose and Ganguly 1995). Starting materials were sealed in platinum capsules which were insulated from the graphite heater by a small $\mathrm{Al}_{2} \mathrm{O}_{3}$ sleeve and separated from the thermocouple tip by a $0.5-\mathrm{mm} \mathrm{Al}_{2} \mathrm{O}_{3}$ disc.

All experiments were performed using the 'piston-out' method, where the pressure was first raised to a few kilobars. The temperature was then increased to ca. $450{ }^{\circ} \mathrm{C}$ to soften the Pyrex, following which the pressure was increased up to ca. 0.5 kbar higher than the desired pressure and the temperature was increased to the nominal temperature of the run. Finally, the pressure was lowered to the required run pressure.

As a check on pressure calibration, the position of the univariant reaction $\mathrm{Fe}_{2} \mathrm{SiO}_{4}+\mathrm{SiO}_{2}=2 \mathrm{FeSiO}_{3}$ was reversed, as described by Klemme and O'Neill (1997). No melt could be found in the calibration experiments, indicating perfectly dry conditions. Another important item of evidence for the validity of our pressure calibration of the piston-cylinder apparatus at the Research School of Earth Sciences, is the essentially perfect agreement of thermodynamic data for $\mathrm{MgCr}_{2} \mathrm{O}_{4}$ derived from a high-pressure, high-temperature study (Klemme and O'Neill 1997) and from subsequent calorimetric measurements for $\mathrm{MgCr}_{2} \mathrm{O}_{4}$ (S. Klemme,

compositions (SM 3 and SM 4, see text). SM 25 and SM 28 consist of $\mathrm{MgAl}_{2} \mathrm{O}_{4}, \mathrm{Mg}_{2} \mathrm{SiO}_{4}$ and orthopyroxene and clinopyroxenes

\begin{tabular}{llllll}
\hline Bulk $(w t \%)$ & SM 6/9/15 & SM 25 & SM 28 & SM 4 & SM 3 \\
\hline $\mathrm{MgO}$ & 30.7 & 36.4 & 39.6 & - & - \\
$\mathrm{CaO}$ & 6.9 & 5.5 & 6.2 & - & - \\
$\mathrm{SiO} 2$ & 39.7 & 36.5 & 38.1 & - & - \\
$\mathrm{Al}_{2} \mathrm{O}_{3}$ & 22.7 & 21.4 & 16.1 & $\mathrm{Py}_{90} \mathrm{Gr}_{10}$ & - \\
$\mathrm{Garnet}_{\mathrm{Opx}}^{\mathrm{Cpx}}$ & - & - & - & - & - \\
$\mathrm{Cy}$ & - & $10 \%(\mathrm{wt}) \mathrm{Al}_{2} \mathrm{O}_{3}$ & $5 \%(\mathrm{wt}) \mathrm{Al}_{2} \mathrm{O}_{3}$ & - \\
\hline
\end{tabular}


H. StC. O’Neill, W. Schnelle, E. Gmelin, unpublished). In particular, the slope of this reaction is constrained by reversal brackets at $100{ }^{\circ} \mathrm{C}$ intervals from 1000 to $1500{ }^{\circ} \mathrm{C}$ inclusive, using $\mathrm{NaCl}-\mathrm{Pyrex}$ assemblies identical to those used here. The internal consistency of these results argues against any gross change in the behaviour of the $\mathrm{NaCl}-$ Pyrex cells with increasing temperature above the $1050^{\circ} \mathrm{C}$ at which we reversed the fayalite-ferrosilite-quartz transition.

Temperatures were measured with $\mathrm{Pt}_{94} \mathrm{Rh}_{6}-\mathrm{Pt}_{70} \mathrm{Rh}_{30}$ thermocouples (type $\mathrm{B}$ ) inserted axially into the assembly inside two- or four-bore high-purity $\mathrm{Al}_{2} \mathrm{O}_{3}$ tubing. A thermocouple from the same spools of wire as used for the thermocouples in our piston-cylinder experiments was calibrated directly against the melting point of $\mathrm{Au}$ at $1 \mathrm{~atm}$ pressure, with a result $\left(1065^{\circ} \mathrm{C}\right)$ which is within $1{ }^{\circ} \mathrm{C}$ of the accepted temperature. Type $\mathrm{B}$ thermocouples are much more resistant to contamination at high temperature than the more commonly used $\mathrm{Pt}-\mathrm{Pt}_{90} \mathrm{Rh}_{10}$ (type $\mathrm{S}$ ) or $\mathrm{Pt}-\mathrm{Pt}_{87} \mathrm{Rh}_{13}$ (type $\mathrm{R}$ ) thermocouples, although they are somewhat less sensitive. Nevertheless, because thermocouple drift due to contamination is always a potential hazard in piston-cylinder experiments at high temperatures (Holloway and Wood 1988), temperatures in some runs (particularly the higher temperature ones) were additionally monitored with a second thermocouple of $\mathrm{W}_{75} \mathrm{Re}_{25}-\mathrm{W}_{97} \mathrm{Re}_{3}$ (type C). Temperatures as measured by the two thermocouples differed only by a maximum of $10{ }^{\circ} \mathrm{C}$. The sample was placed in the hot spot of the assembly which was found in previous calibrations in this laboratory (W.O. Hibberson, personal communication). This assembly has also previously been tested for temperature against the melting point of gold (cf. Mirwald and Kennedy 1979). Possible pressure effects on the emf of thermocouple pairs were neglected. The temperature uncertainties are estimated to be less than $\pm 10^{\circ} \mathrm{C}$ at lower temperatures, increasing to about $\pm 15^{\circ} \mathrm{C}$ at $1500{ }^{\circ} \mathrm{C}$.

In order to minimize contamination of thermocouples in the lengthy runs it was found necessary to use high-purity inner components in the run assemblies. In this study inner parts of the pressure assembly consisted of high-purity $\mathrm{Al}_{2} \mathrm{O}_{3}$ thermocouple sleeves, which are chemically more inert than the mullite sleeves previously used in this laboratory.

\section{Analytical techniques}

Each experimental run product was sectioned longitudinally with a diamond saw, and one half was mounted in epoxy and polished using a series of diamond pastes with a finish of $0.3 \mu \mathrm{m} \mathrm{Al} \mathrm{Al}_{2} \mathrm{O}_{3}$ polishing powder (Linde B). Run products were carbon coated and analysed on a Cameca 'Microbeam' electron microprobe at the Research School of Earth Sciences (ANU) and on a JEOL 6400 scanning electron microprobe (SEM) in energy dispersive mode (EDS) at the Electron Microprobe Unit (EMU) at ANU. Accel- erating voltage was $15 \mathrm{keV}$, ZAF correction was applied in all analyses (Ware 1991). Starting material compositions were also analysed using powder X-ray techniques. The standard materials for electron microprobe analyses were natural diopside, garnet and spinel, as well as synthetic corundum crystals. Standards were analysed with both the SEM-EDS as well with the electron microprobe (EDS and WDS). Analytical results obtained with both techniques agree well with each other.

\section{Results}

Table 2 lists experimental conditions, start material information and the phases present in each experiment. Analytical results are presented in Table 3 . The position of the univariant reaction is illustrated in Fig. 2.

\section{Comparison with previous studies and discussion}

The transition from garnet lherzolite to spinel lherzolite

The transition from garnet lherzolite to spinel lherzolite was first investigated in CMAS by MacGregor (1965) in the temperature range from 1100 to $1500{ }^{\circ} \mathrm{C}$. A similar study by Kushiro and Yoder (1966) $\left(1175-1500{ }^{\circ} \mathrm{C}\right)$ yielded only slightly differing results, probably due to the pressure correction applied. Both MacGregor (1965) and Kushiro and Yoder (1966) proposed a straight line of the univariant reaction in P-T space, in contrast to subsequent work. Studies by Jenkins and Newton (1979) and O'Neill (1981) found, in well-reversed experiments, a curved transition below temperatures of $1300{ }^{\circ} \mathrm{C}$, resulting in a slope of the reaction that was nearly parallel to the temperature axis at temperatures below $1000^{\circ} \mathrm{C}$. In order for these latter results to be compatible with the higher temperature observations, the transition must show strong curvature in P-T space at temperatures between 1000 and $1300{ }^{\circ} \mathrm{C}$. This has the consequence that garnet lherzolite with typical mantle $\mathrm{Mg} /(\mathrm{Mg}+\mathrm{Fe})=$
Table 2 Starting materials, run conditions, results. $T$ Temperature in ${ }^{\circ} \mathrm{C}, P$ pressure in kbar, spi spinel, cpx clinopyroxene, opx orthopyroxene, $f o$ forsterite, gnt garnet, quench melt. Starting material mixtures are explained in the text

\begin{tabular}{llllll}
\hline Run no. & Starting material & $\mathrm{T}\left({ }^{\circ} \mathrm{C}\right)$ & $\mathrm{P}$ (kbar) & Duration (h) & Phases present \\
\hline C234-S 23 & SM 9 & 1200 & 18 & 120 & fo opx cpx spi, minor gnt \\
C276-S 29 & SM 15 & 1200 & 20 & 360 & fo opx cpx gnt, minor spi \\
C163-S 10 & SM 6 & 1400 & 23 & 72 & fo opx cpx spi, minor gnt \\
C246-S 26 & SM 15 & 1400 & 24 & 72 & fo opx cpx spi, minor gar \\
C231-S 21 & SM 15 & 1400 & 25 & 72 & fo opx cpx gnt, minor spi \\
C191-S 14 & SM 9 & 1400 & 27 & 144 & fo opx cpx gnt, minor spi \\
C418-S 75 & SM 15 & 1475 & 25 & 48 & opx spi gnt \\
C332-S 54 & SM 15 & 1500 & 27 & 24 & fo opx cpx gnt, trace spi \\
C278-S 30 & SM 9 & 1500 & 26 & 15 & fo opx cpx spi, minor gnt \\
C470-S 89 & SM 25 & 1400 & 23 & 44 & fo opx cpx spi \\
C467-S 87 & SM 25 & 1450 & 23 & 24 & fo opx cpx spi \\
C468-S 88 & SM 25 & 1475 & 23 & 24 & fo opx spi quench \\
C473-S 90 & SM 25 & 1500 & 23 & 12 & fo spi quench \\
C478-S 92 & SM 28 & 1400 & 23 & 44 & fo opx cpx spi \\
C485-S 94 & SM 28 & 1425 & 23 & 48 & fo opx cpx spi \\
C483-S 93 & SM 28 & 1450 & 23 & 24 & fo opx cpx spi \\
C488-S 95 & SM 28 & 1475 & 23 & 24 & fo opx cpx spi \\
C477-S 91 & SM 28 & 1500 & 23 & 12 & opx spi quench \\
\hline
\end{tabular}

${ }^{\text {a }}$ Contained partial melt 


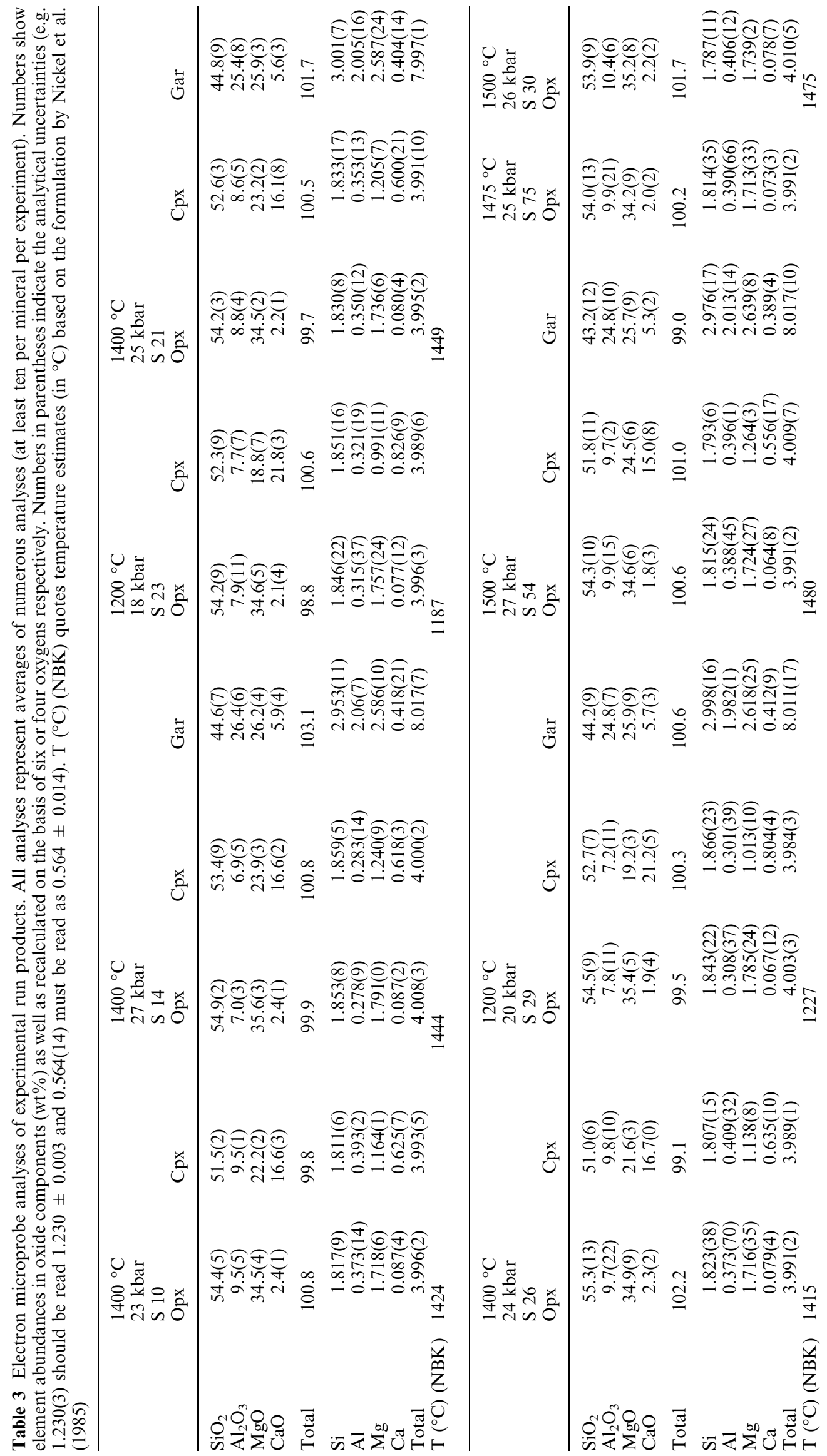




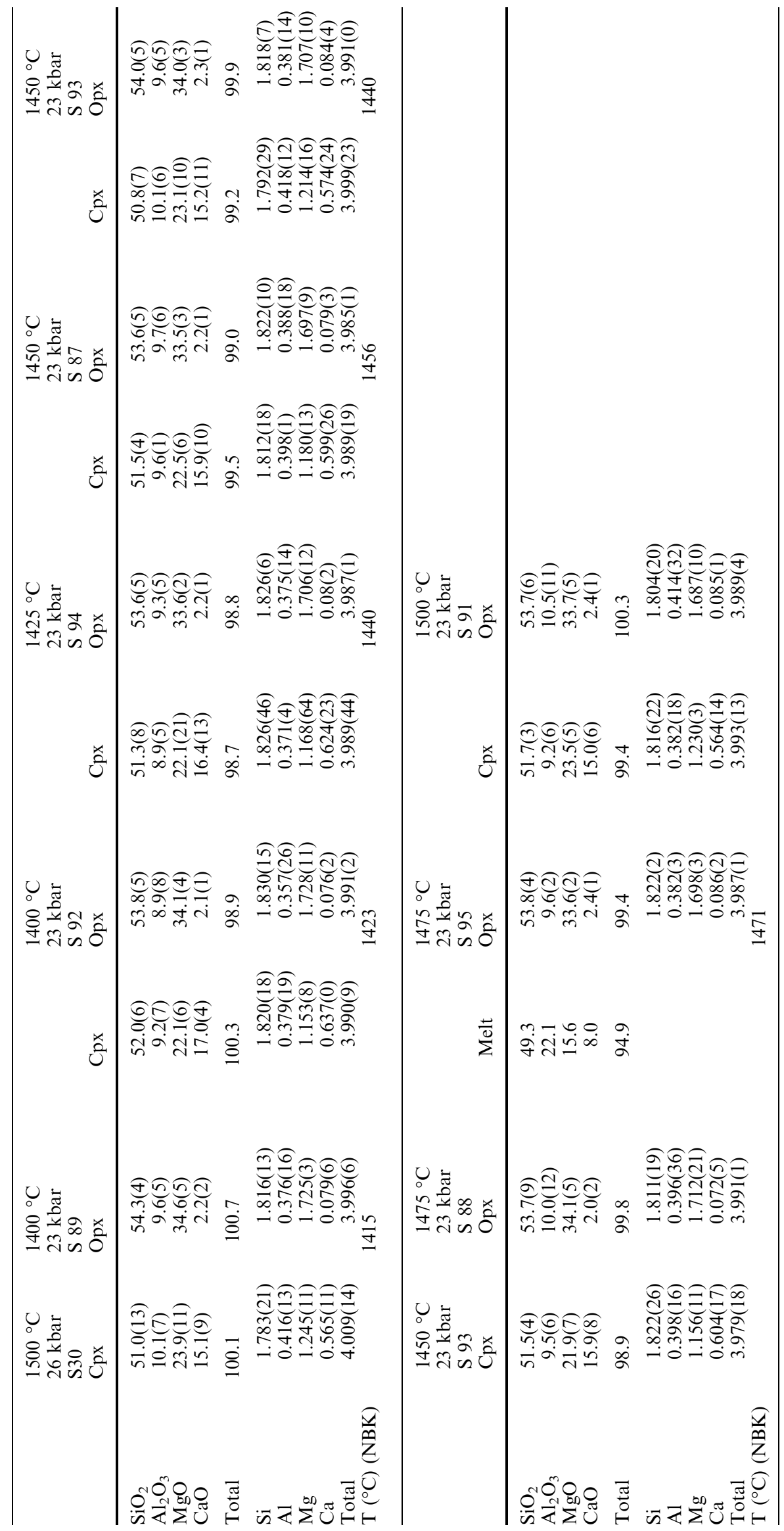




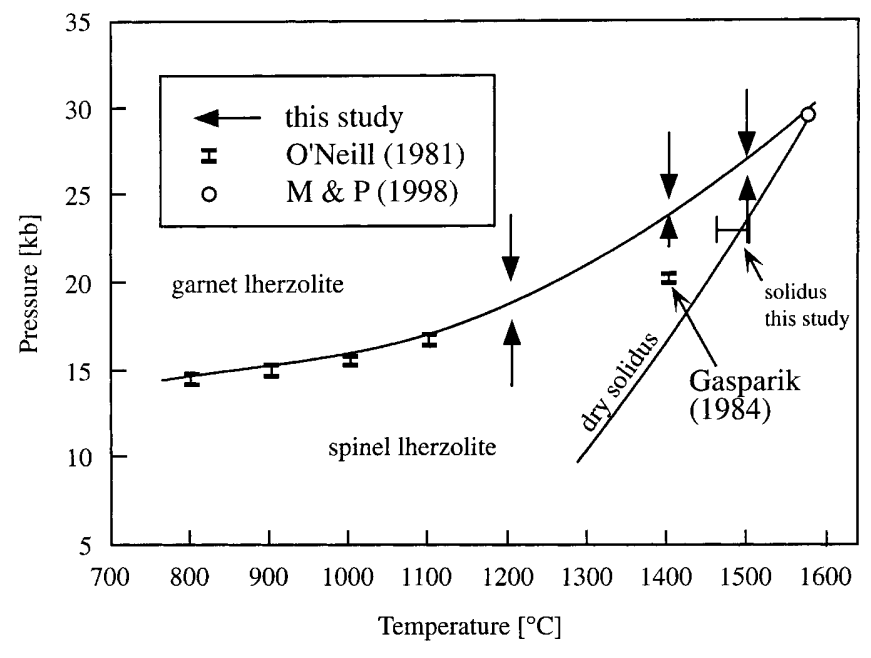

Fig. 2 The transition from garnet lherzolite to spinel lherzolite in the system CMAS. Experimentally derived brackets from this study (arrows) are compared with results by O'Neill (1981) [corrected for friction; see text], and one datum from Milholland and Presnall $(M \& P)(1998)$ and Gasparik (1984) respectively. The present results agree well with brackets (see text) in the low-temperature part of the diagram $\left(800-1200{ }^{\circ} \mathrm{C}\right.$ ) but for higher temperatures there are considerable differences between the present results and a published datum from Gasparik (1984). A recent datum by Milholland and Presnall (1998), however, is in perfect agreement with the position of the current univariant curve. The transition curve in this diagram is eye-fitted. The dry solidus is taken from Presnall et al. (1979) and Gudfinnsson and Presnall (1996). Our data on the position of the solidus (at $23 \mathrm{kbar}$ ) agree well with data from Presnall's laboratory

0.9 is not stable at crustal pressures (but see O'Neill 1981 for a discussion of the effect of $\mathrm{Fe}^{2+}$ on increasing the stability of garnet plus olivine to lower pressures).

However, the information about the high-temperature part of the univariant reaction in CMAS is, unfortunately, controversial (Fig. 1). MacGregor (1965) and O'Hara et al. (1971) performed bracketing experiments, but microprobe analyses of the experimental charges were not possible so that the attainment of equilibrium could not be assessed. Kushiro and Yoder (1966) determined approximate stability fields of spinel and garnet lherzolite respectively, but their experiments remained unreversed. Besides, uncertain pressure corrections in the different solid-media pressure devices further complicated interlaboratory comparison of early experimental results (Koziol and Newton 1988).

Prior to the commencement of this study, the only experimental datum on the transition from spinel lherzolite to garnet lherzolite in the CMAS system at temperatures higher than $1200{ }^{\circ} \mathrm{C}$, which is both reversed and analysed with electron microprobe, was from Gasparik (1984). Recently, Milholland and Presnall (1998) have reported a experimental datum at $1575^{\circ} \mathrm{C}$ and $30 \mathrm{kbar}$ for the transition from garnet to spinel lherzolite exactly on the dry solidus.

The present experimental brackets agree well with a smooth, curved extrapolation of results from the studies of Jenkins and Newton (1979) and O'Neill (1981) at 800 to $1100{ }^{\circ} \mathrm{C}$, and through the reversal bracket of Patera
(1982) at $1200{ }^{\circ} \mathrm{C}$ (pressure corrected for friction, cf. Wood and Holloway [1984]), to the results of Milholland and Presnall (1998) on their solidus at $1575^{\circ} \mathrm{C}$. Note that the studies in the low-temperature range from 800 to $1100{ }^{\circ} \mathrm{C}$ agree well with each other, provided that a pressure correction of $-10 \%$ is applied to O'Neill's (1981) data because of the rigid talc-Pyrex assembly he used (Green et al. 1966).

However, our present results disagree considerably with the datum from Gasparik (1984), who determined the equilibrium to lie between 20.3 and $20.8 \mathrm{kbar}$ at $1400{ }^{\circ} \mathrm{C}$, versus our bracket of 24 to $25 \mathrm{kbar}$ at the same temperature. Gasparik's pressures were corrected for friction because of the rigid talc-Pyrex pressure assembly used in his experiments. Although this empirical correction may overestimate the friction at $1400{ }^{\circ} \mathrm{C}$ in Gasparik's (1984) experiments, this cannot, however, fully explain the discrepancy between the results of Gasparik (1984) and this study. Apart from pressure, two other possibilities are errors in temperature measurements (the difference in pressure would correspond

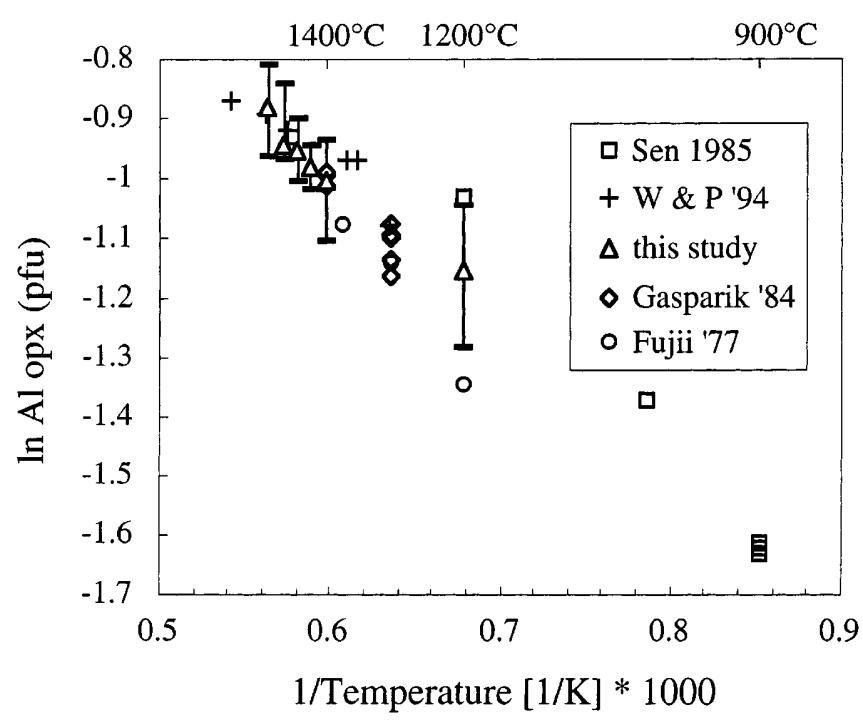

Fig. 3 The solubility of alumina in orthopyroxene ( $A l p f u \mathrm{Al}$ atoms calculated per formula unit of six oxygens) in equilibrium with spinel lherzolite in the system CMAS. Experimental results from reversed studies of Gasparik (1984), Sen (1985) and this study are compared. Also depicted are experimental results of an unreversed study of Walter and Presnall (1994) ( $W \& P$ '94), from experiments in the system $\mathrm{Na}_{2} \mathrm{O}-\mathrm{CaO}-\mathrm{MgO}-\mathrm{Al}_{2} \mathrm{O}_{3}-\mathrm{SiO}_{2}$. Walter and Presnall's (1994) results agree well with the present experiments and with those of the other studies, indicating that there is only a minor influence of sodium on the solubility of alumina in orthopyroxene. Sen (1985) presents reversal experiments from 900 to $1200{ }^{\circ} \mathrm{C}$. Good agreement is found between his results and experimental results of this study; one of Sen's data at $1200{ }^{\circ} \mathrm{C}$, however, disagrees with the results presented and with combined results from the other studies. Experiments depicted in this diagram were performed at a range of different pressures, indicating that the alumina solubility in orthopyroxene in the spinel lherzolite stability field does not significantly depend on pressure. For clarity, the uncertainties in the reversed mineral compositions are only indicated in our data. Walter and Presnall (1994) quote analytical uncertainties (of about the same magnitude as in this study) of their unreversed experiments, while Fujii (1977), Gasparik (1984) and Sen (1985) do not quote any uncertainties 
to a temperature error of about $150{ }^{\circ} \mathrm{C}$, see Fig. 2) or metastable growth of garnet at the expense of spinel (etc.) in Gasparik's experiment at $20.8 \mathrm{kbar}$, or of spinel at the expense of garnet in our experiment at 24 kbar. Gasparik's reversals of the alumina content of pyroxenes are in good agreement with the results of our study (Fig. 3), which would tend to argue against errors in temperature measurement as the explanation, although the uncertainties in alumina contents are sufficiently large that this possibility cannot be completely dismissed. As for metastable reactions, the longer run times of our experiments $\left(\sim 72 \mathrm{~h}\right.$ at $\left.1400{ }^{\circ} \mathrm{C}\right)$ compared to the $\sim 24$ h of those of Gasparik (1984) argues for our results being the more reliable.

\section{The solubility of alumina in pyroxenes}

The 'indirect approach' as described here was first used by Obata (1976), who deduced the position of reaction (1) using the intersection of the experimentally determined isopleths of $\mathrm{Al}_{2} \mathrm{O}_{3}$ dissolved in orthopyroxene in the MAS system in both the garnet and the spinel lherzolite stability fields. Herzberg (1978) investigated in an analogous study the isopleths of alumina of clinopyroxene, coming to somewhat different conclusions. Both studies suffered from a lack of microprobe analyses of the pyroxenes and the experiments were not reversed.

More recently, Sen (1985) presented reversed experimental data in the spinel stability field that are in good agreement with results presented here. All of his data, but one, compare well with the present results (Fig. 3). An experimental study in the system $\mathrm{Na}_{2} \mathrm{O}-$ $\mathrm{CaO}-\mathrm{MgO}-\mathrm{Al}_{2} \mathrm{O}_{3}-\mathrm{SiO}_{2}$ (Walter and Presnall 1994) presents results that are also in good agreement with the results of this study (Fig. 3), indicating that the influence of sodium on the activity of alumina in orthopyroxene can be neglected. However, like most studies of melting equilibria, Walter and Presnall's experiments were unreversed. Of all alumina solubility experiments in the spinel lherzolite stability field, only those of Fujii (1977), Gasparik (1984) and Sen (1985) were both reversed and analysed with electron microprobe, but only those of Sen (1985) report uncertainties in pyroxene compositions.

Run durations in Fujii's (1977) experiments are very short (only a few hours). Comparing his run durations with the present experience with reaction rates in CMAS, a lack of complete equilibrium in his experiments remains possible.

As a further test for consistency, nominal experimental temperatures (this study) were compared to calculated temperatures based on the exchange of $\mathrm{Ca}$ and $\mathrm{Mg}$ between orthopyroxene and clinopyroxene, using the thermometric formulation of Nickel et al. (1985). Results of the thermometry (Table 3) indicate excellent agreement between the present experiments and Nickel et al.'s (1985) formulation.

\section{Some notes on two recent abstracts}

Longhi (1998) locates the position of the anhydrous solidus in CMAS higher than previously envisaged (by $95^{\circ} \mathrm{C}$ at $28 \mathrm{kbar}$ ). $\mathrm{He}$ explains the temperature differences between his experiments (conducted with a $\mathrm{BaCO}_{3}$ pressure medium) and those of Presnall and co-workers (e.g. Walter and Presnall 1994; Gudfinnsson and Presnall 1996) by fluxed melting induced by diffusion of $\mathrm{H}_{2} \mathrm{O}$ or boron into the sample from the talc/Pyrex used in Presnall's (University of Texas, Dallas) laboratory.

Although we do not present many data on the position of the solidus, our observations place the solidus below $1500{ }^{\circ} \mathrm{C}$ at 23 kbar (Table 2), in good agreement with Walter and Presnall's (1994) and Gudfinnsson and Presnall's (1996) data.

Furthermore, in a recent abstract Longhi and Baker (1999) find the position of the transition between garnet lherzolite and spinel lherzolite in CMAS at $1500{ }^{\circ} \mathrm{C}$ between 20 and $22 \mathrm{kbar}$ using $\mathrm{BaCO}_{3}$ pressure medium, and 21 and $23 \mathrm{kbar}$ using $\mathrm{CaF}_{2}$. This is considerably lower than our bracket between 26 and 27 kbar (Table 2). Longhi and Baker (1999) compare their results with previous work by Gudfinnsson and Presnall (1996) and others, and again attribute the differences in pressure to talcbreakdown of the talc-Pyrex pressure assemblies used in Presnall's laboratory (Longhi and Baker 1999) or to melting of the Pyrex glass in the talc-Pyrex assemblies (J. Longhi, his review of the present paper). However, the present results may shed some new light on the current debate, as our pressure assembly consists of a dry $\mathrm{NaCl}-$ Pyrex assembly, which has been calibrated independently (see Klemme and O'Neill 1997). As our data on both the position of the garnet-spinel transition and the solidus agree well with those of Presnall and co-workers, we conclude that talc breakdown is not the correct explanation. As our experiments do not indicate melting of the Pyrex glass either, we also suggest that melting of Pyrex and associated anvil effects in our experiments (J. Longhi, personal communication) cannot account for the large differences between Longhi and Baker's (1999) data and the present results.

We note that the recent observations of Longhi (1998) and Longhi and Baker (1999) could also be accounted for by a systematic error in temperature of about $100{ }^{\circ} \mathrm{C}$. Our experience with long-duration runs at temperatures higher than $1200{ }^{\circ} \mathrm{C}$ suggest that thermocouple drift of W-Re thermocouples used by Longhi (personal communication, Longhi's review of this paper) could be the cause for the differing results of Longhi and Baker (1999), especially as the transition is strongly curved at high temperatures. However, this remains only speculation until more details (as thermocouple calibration, pressure calibration, mineral compositions, run durations etc.) of Longhi and Baker's (1999) study are published.

\section{Conclusions and implications}

This study presents new and reversed experimental results on the transition from garnet lherzolite to spinel lherzolite in a simplified system. The transition pressure at temperatures close to the solidus is found to be substantially higher than previously estimated.

Minor elements like $\mathrm{Cr}$ and $\mathrm{Fe}^{2+}$ are known to have a substantial effect on the position of the transition. $\mathrm{Cr}$ is known to preferentially stabilize spinel-bearing assemblages (Klemme and O'Neill 1998), while $\mathrm{Fe}^{2+}$ has the opposite effect, shifting the transition to lower pressures (e.g. MacGregor 1970; O'Neill 1981). Thus, rocks containing coexisting almandine and fayalite ('eulysites') occur in regionally metamorphosed crustal rocks of the amphibolite facies (e.g. Woodland et al. 1995). The effect of $\mathrm{Fe}^{2+}$ is to shift the transition to about 2 to $3 \mathrm{kbar}$ 
lower pressure for the typical mantle $\mathrm{Mg} /\left(\mathrm{Mg}+\mathrm{Fe}^{2+}\right)$ of 0.9 (O'Neill 1981). For fertile mantle with high $\mathrm{Al}(\mathrm{Al}+\mathrm{Cr})$ ratios, the effect of $\mathrm{Cr}$ on the pressure at which garnet appears is only poorly constrained to date, but probably small (Caroll-Webb and Wood 1986; Klemme 1998). The position of the transition in natural compositions is therefore likely to be substantially higher than in some recent estimates (e.g. Hirschmann and Stolper 1996) but consistent with other studies in natural compositions (Green and Falloon 1998; Robinson and Wood 1998; Koga et al. 1999).

The confirmation of a relatively high pressure for the garnet/spinel transition leaves the paradox of the socalled 'garnet signature' in MORB unresolved; indeed, our results worsen the paradox, since we place the transition even higher than earlier studies (e.g. Gasparik 1984). The paradox is that if melting during adiabatic upwelling beneath a mid-ocean ridge begins at the depth required for the stability of garnet in peridotitic compositions, simple melting models (e.g. McKenzie and Bickle 1988) predict that the amount of melt produced should be much greater than the $7 \mathrm{~km}$ or so that is observed seismically for the thickness of the oceanic crust.

There are several possible solutions to this paradox. Firstly, the simple melting models presently available may be in error, particularly because of the assumption of a linear increase in melt productivity with temperature above the solidus. For example, Asimov et al. (1995) have argued that melting may cease as upwelling mantle crosses the garnet-spinel transition, due to the entropy of this reaction. It is also possible that $\mathrm{C}-\mathrm{O}-\mathrm{H}-$ silicate fluids, which have much greater segregation velocities than basaltic melts, may scavenge highly incompatible trace elements from regions outside the zones of normal melt productivity, thus imparting a garnet signature, particularly as regards the U-Th disequilibrium series, to aggregated melts that are mostly derived from the spinel lherzolite facies (U. Faul, personal communication). Secondly, the primitive MORB parental magma probably undergoes extensive fractional crystallization of olivine (e.g. Green and Falloon 1998); hence the amount of melt produced is actually much greater than that inferred from seismic imaging of the thickness of the oceanic crust. Melting may also begin in garnet pyroxenite veins that are believed to be stable at lower pressures than garnet lherzolite (e.g. Hirschmann and Stolper 1996). Finally, we note that recent trace element partitioning studies indicate that the melt/crystal partitioning characteristics of clinopyroxene approach those of garnet, both for the heavy rare earth elements (HREE) and for Th versus U, as the clinopyroxene becomes more aluminous and less calcic (Wood and Blundy 1997; Wood et al. 1998). This raises the possibility that the so-called 'garnet signature' in MORB may in fact be due to clinopyroxene of a composition appropriate for near-solidus temperatures in the spinel lherzolite stability field; that is, with $\mathrm{Ca} /(\mathrm{Ca}+$ $\mathrm{Mg})<0.35$, and alumina contents near $10 \%$ (wt), as found in this study.
Acknowledgements We thank S.F. Foley and J. Longhi for constructive reviews and for sharing some unpublished information with us. We would also like to thank all members of the Petrochemistry and Experimental Petrology (PEP) group at the Reset School of Earth Sciences (Dave Green, Steve Eggins, Greg Yaxley, Uli Faul, Sue Kesson, Martin Cmíral, Jörg Hermann, Alistair Hack, Paul Hoskin, John Mavrogenes, Mike Shelley, Nick Ware, Wayne Taylor, Linda Hanley, Andrew Berry, Wilfred Lus and Bob Loucks) for discussions mostly during the PEP Friday lunch-time meetings. SK would like to thank the Australian National University (ANU) for a $\mathrm{PhD}$ scholarship. Special thanks to W.O. Hibberson, Dean R Scott, Paul Willis and Alan Major for friendship and support in the laboratory.

\section{References}

Akella J (1976) Garnet pyroxene equilibria in the system $\mathrm{CaSiO}_{3}-$ $\mathrm{MgSiO}_{3}-\mathrm{Al}_{2} \mathrm{O}_{3}$ and in a natural mineral mixture. Am Mineral 61: $589-598$

Allègre CJ, Hamelin B, Dupré B (1984) Statistical analysis of isotopic ratios in MORB: the mantle blob cluster model and the convective regime of the mantle. Earth Planet Sci Lett 71: 71-84

Asimov PD, Hirschmann MM, Ghiorso MS, O'Hara MJ, Stolper EM (1995) The effect of pressure-induced solid-solid phase transitions on decompression melting of the mantle. Geochim Cosmochim Acta 59: 4489-4506

Atlas L (1952) The polymorphism of $\mathrm{MgSiO}_{3}$ and solid-state equilibria in the system $\mathrm{MgSiO}_{3}-\mathrm{CaMgSi}_{2} \mathrm{O}_{6}$. J Geol 60: 125147

Beattie P (1993a) The generation of uranium series disequilibria by partial melting of spinel peridotite: constraints from partitioning studies. Earth Planet Sci Lett 117: 379-391

Beattie P (1993b) Uranium-thorium disequilibria and partitioning on melting of garnet peridotite. Nature 363: 63-65

Bose K, Ganguly J (1995) Quartz-coesite transition revisited: reversed experimental determination at $500-1200{ }^{\circ} \mathrm{C}$ and retrieved thermochemical properties. Am Mineral 80: 231238

Boyd FR, England JL (1960) Apparatus for phase-equilibrium measurements at pressures up to 50 kbar and temperatures up to $1750{ }^{\circ} \mathrm{C}$. J Geophys Res 65: 741-748

Brey GP, Nickel KG, Kogarko L (1986) Garnet-pyroxene equilibria in the system $\mathrm{CaO}-\mathrm{MgO}-\mathrm{Al}_{2} \mathrm{O}_{3}-\mathrm{SiO}_{2}$ (CMAS): prospects for simplified ( $\mathrm{T}$ 'independent') lherzolite barometry and an eclogite-barometer. Contrib Mineral Petrol 92: 448-455

Carlson WD, Lindsley DH (1988) Thermochemistry of pyroxenes on the join $\mathrm{Mg}_{2} \mathrm{Si}_{2} \mathrm{O}_{6}-\mathrm{CaMgSi}_{2} \mathrm{O}_{6}$. Am Mineral 73: 242-252

Caroll-Webb SA, Wood BJ (1986) Spinel-pyroxene-garnet relationships and their dependence on $\mathrm{Cr} / \mathrm{Al}$ ratio. Contrib Mineral Petrol 92: 471-480

Danckwerth PA, Newton RC (1978) Experimental determination of the spinel peridotite to garnet peridotite reaction in the system $\mathrm{MgO}-\mathrm{Al}_{2} \mathrm{O}_{3}-\mathrm{SiO}_{2}$ in the range $900-1100{ }^{\circ} \mathrm{C}$ and $\mathrm{Al}_{2} \mathrm{O}_{3}$ isopleths of enstatite in the spinel field. Contrib Mineral Petrol 66: 189-201

Fockenberg T, Schreyer W(1997) Synthesis and chemistry of unusual excess- $\mathrm{Si}$ aluminous enstatite in the system $\mathrm{MgO}-\mathrm{Al}_{2} \mathrm{O}_{3-}$ $\mathrm{SiO}_{2}$ (MAS). Eur J Mineral 9: 509-518

Fujii T (1977) Pyroxene equilibria in spinel lherzolite. Carnegie Inst Wash Year Book 76: 569-572

Gasparik T (1984) Two-pyroxene thermobarometry with new experimental data in the system $\mathrm{CaO}-\mathrm{MgO}-\mathrm{Al}_{2} \mathrm{O}_{3}-\mathrm{SiO}_{2}$. Contrib Mineral Petrol 87: 87-97

Gasparik T, Newton RC (1984) The reversed alumina contents of orthopyroxene in equilibrium with spinel and forsterite in the system $\mathrm{MgO}-\mathrm{Al}_{2} \mathrm{O}_{3}-\mathrm{SiO}_{2}$. Contrib Mineral Petrol 85: 186-196

Green DH, Falloon TJ (1998) Pyrolite: a Ringwood concept and its current expression. In: Jackson I (ed) The Earth's mantle: composition, structure and evolution. Cambridge University Press, Cambridge, pp 311-380 
Green TH, Ringwood AE, Major A (1966) Friction effects and pressure calibration in a piston-cylinder high pressure-temperature apparatus. J Geophys Res 71: 3589-3594

Gudfinnsson GH, Presnall DC (1996) Melting relations of model lherzolite in the system $\mathrm{CaO}-\mathrm{MgO}-\mathrm{Al}_{2} \mathrm{O}_{3}-\mathrm{SiO}_{2}$ at $2.4-3.4 \mathrm{GPa}$ and the generation of komatiites. J Geophys Res 101: 2770127709

Herzberg CT (1978) Pyroxene geothermometry and geobarometry: experimental and thermodynamic evaluation of some subsolidus reactions involving pyroxenes in the system $\mathrm{CaO}-\mathrm{MgO}-\mathrm{Al}_{2} \mathrm{O}_{3}-\mathrm{SiO}_{2}$. Geochim Cosmochim Acta 42: 945-957

Herzberg CT, Chapman NA (1976) Clinopyroxene geothermometry of spinel lherzolites. Am Mineral 61: 626-637

Hirschmann MM, Stolper EM (1996) A possible role for garnet pyroxenite in the origin of the 'garnet signature' in MORB. Contrib Mineral Petrol 124: 185-208

Holloway JR, Wood BJ (1988) Simulating the Earth. Unwin Hyman, London

Howells S, O'Hara MJ (1978) Low solubility of alumina in enstatite and uncertainties in estimated paleogeotherms. Philos Trans R Soc Lond 288: 471-486

Iwamori H, McKenzie D, Takahashi E (1995) Melt generation by isentropic upwelling. Earth Planet Sci Lett 134: 253-266

Jenkins DM, Newton RC (1979) Experimental determination of the spinel peridotite to garnet peridotite inversion at $900{ }^{\circ} \mathrm{C}$ and $1000{ }^{\circ} \mathrm{C}$ in the system $\mathrm{CaO}-\mathrm{MgO}-\mathrm{Al}_{2} \mathrm{O}_{3}-\mathrm{SiO}_{2}$, and at $900{ }^{\circ} \mathrm{C}$ with natural garnet and olivine. Contrib Mineral Petrol 68: 407-419

Kay RW, Gast PW (1973) The rare earth content and origin of alkali-rich basalts. J Geol 81: 653-682

Klein EM, Langmuir CH (1987) Global correlations of ocean ridge basalt chemistry with axial depth and crustal thickness. J Geophys Res 92: 8089-8115

Klemme S (1998) Experimental and thermodynamic studies of upper mantle phase relations. PhD Thesis, Australian National University

Klemme S, O'Neill HStC (1997) The reaction $\mathrm{MgCr}_{2} \mathrm{O}_{4}+\mathrm{SiO}_{2}=\mathrm{Cr}_{2} \mathrm{O}_{3}+\mathrm{MgSiO}_{3}$ and the free energy of formation of magnesiochromite $\left(\mathrm{MgCr}_{2} \mathrm{O}_{4}\right)$. Contrib Mineral Petrol 130: 59-65

Klemme S, O'Neill HStC (1998) The partitioning of chromium between orthopyroxene and spinel in the system $\mathrm{MgO}-\mathrm{Al}_{2} \mathrm{O}_{3}$ $\mathrm{SiO}_{2}-\mathrm{Cr}_{2} \mathrm{O}_{3}$. Mineral Mag 62A: 789-790

Koga KT, Shimizu N, Grove TL (1999) Experimental determination of garnet-spinel coexisting lherzolite facies and trace element distribution. Ofioliti 24: 114-115

Koziol AM, Newton RC (1988) Redetermination of the anorthite breakdown reaction and improvement of the plagioclase-garnet- $\mathrm{Al}_{2} \mathrm{SiO}_{5}$-quartz geobarometer. Am Mineral 73: 216-223

Kushiro I, Yoder HS Jr (1966) Anorthite-forsterite and anorthiteenstatite reactions and their bearing on the basalt-eclogite transformation. J Petrol 7: 337-362

LaTourrette TK, Kennedy AK, Wasserburg GJ (1993) Thorium-uranium fractionation by garnet: evidence for a deep source and rapid rise of oceanic basalts. Science 261: 739742

Lindsley DH, Grover JE, Davidson PM (1981) The thermodynamics of the $\mathrm{Mg}_{2} \mathrm{Si}_{2} \mathrm{O}_{6}-\mathrm{CaMgSi}_{2} \mathrm{O}_{6}$ join: a review and an improved model. In: Newton RC, Navrotsky A, Wood BJ (eds) Advances in physical geochemistry, vol 1. Springer, Berlin Heidelberg New York, pp 149-175

Longhi J (1998) The anhydrous mantle solidus? New experiments in CMAS. EOS (Suppl), AGU Fall Meeting 79: 1005

Longhi J, Baker MB (1999) The spinel/garnet transition in CMAS. EOS (Suppl), AGU Spring Meeting 80: 379

MacGregor ID (1965) Stability fields of spinel and garnet peridotites in the synthetic system $\mathrm{MgO}-\mathrm{CaO}-\mathrm{Al}_{2} \mathrm{O}_{3}-\mathrm{SiO}_{2}$. Carnegie Inst Wash Year Book 64: 126-134

MacGregor ID (1970) The effect of $\mathrm{CaO}, \mathrm{Cr}_{2} \mathrm{O}_{3}, \mathrm{Fe}_{2} \mathrm{O}_{3}$, and $\mathrm{Al}_{2} \mathrm{O}_{3}$ on the stability of spinel and garnet peridotites. Phys Earth Planet Int 3: 372-377
McKenzie D, Bickle MJ (1988) The volume and composition of melt generated by extension of the lithosphere. J Petrol 29: 625629

Milholland CS, Presnall DC (1998) Liquidus phase relations in the $\mathrm{CaO}-\mathrm{MgO}-\mathrm{Al}_{2} \mathrm{O}_{3}-\mathrm{SiO}_{2}$ system at $3.0 \mathrm{GPa}$; the aluminous pyroxene thermal divide and high-pressure fractionation of picritic and komatiitic magmas. J Petrol 39: $3-27$

Mirwald PM, Kennedy GC (1979) The melting curve of gold, silver and copper to 60 kbar: a reinvestigation. J Geophys Res 84: 6750-6756

Newton RC (1987) Thermodynamic analysis of phase equilibria in simple mineral systems. In: Carmichael ISE, Eugster HP (eds) Thermodynamic modeling of geological materials: minerals, fluids and melts, vol 17. Mineralogical Society of America, Washington, DC, pp 1-33

Nickel KG, Brey G (1984) Subsolidus orthopyroxene-clinopyroxene systematics in the system $\mathrm{CaO}-\mathrm{MgO}-\mathrm{SiO}_{2}$ to $60 \mathrm{~kb}$ : a reevaluation of the regular solution model. Contrib Mineral Petrol 87: 35-42

Nickel KG, Green DH (1985) Empirical geothermobarometry for garnet peridotites and implications for the nature of the lithosphere, kimberlites and diamonds. Earth Planet Sci Lett 73: $158-170$

Nickel KG, Brey GP, Kogarko L (1985) Orthopyroxene-clinopyroxene equilibria in the system $\mathrm{CaO}-\mathrm{MgO}-\mathrm{Al}_{2} \mathrm{O}_{3}-\mathrm{SiO}_{2}$. Contrib Mineral Petrol 91: 44-53

O'Hara MJ, Richardson SW, Wilson G (1971) Garnet-peridotite stability and occurrence in crust and mantle. Contrib Mineral Petrol 32: 48-68

O'Neill HStC (1981) The transition between spinel lherzolite and garnet lherzolite, and its use as a geobarometer. Contrib Mineral Petrol 77: 185-194

Obata $\mathrm{M}(1976)$ The solubility of $\mathrm{Al}_{2} \mathrm{O}_{3}$ in orthopyroxenes in spinel and plagioclase peridotites and spinel pyroxenites. Am Mineral 61: $804-816$

Patera ES (1982) Phase equilibria of the upper Martian mantle: calculations and experiments. PhD Thesis, Arizona State University, Tempe

Perkins D, Newton RC (1980) The composition of coexisting pyroxenes and garnets in the system $\mathrm{CaO}-\mathrm{MgO}-\mathrm{Al}_{2} \mathrm{O}_{3}-\mathrm{SiO}_{2}$ Contrib Mineral Petrol 75: 291-300

Presnall DC, Dixon JR, O'Donnell TH, Dixon SA (1979) Generation of mid-ocean ridge tholeiites. J Petrol 20: 3-35

Robinson JAC, Wood BJ (1998) The depth of the spinel to garnet transition at the peridotite solidus. Earth Planet Sci Lett 164: 277-284

Salters VJM, Hart SR (1989) The hafnium paradox and the role of garnet in the source of mid-ocean-ridge basalts. Nature 342: $420-422$

Sautter V, Jaoul O, Abel F (1988) Aluminium diffusion in diopside using the ${ }^{27} \mathrm{Al}-{ }^{28} \mathrm{Si}$ nuclear reaction: preliminary results. Earth Planet Sci Lett 89: 109-114

Sen $\mathrm{G}$ (1985) Experimental determination of pyroxene compositions in the system $\mathrm{CaO}-\mathrm{MgO}-\mathrm{Al}_{2} \mathrm{O}_{3}-\mathrm{SiO}_{2}$ at $900-1200{ }^{\circ} \mathrm{C}$ and $10-15$ kbar using $\mathrm{PbO}$ and $\mathrm{H}_{2} \mathrm{O}$ fluxes. Am Mineral 70 : 678-695

Shen Y, Forsyth DW (1995) Geochemical constraints on initial and final depths of melting beneath mid-ocean ridges. J Geophys Res 100: 2211-2237

Spear FS (1993) Metamorphic phase equilibria and pressure-temperature-time paths. Mineralogical Society of America, Washington, DC

Walter MJ, Presnall DC (1994) Melting behavior of simplified lherzolite in the system $\mathrm{CaO}-\mathrm{MgO}-\mathrm{Al}_{2} \mathrm{O}_{3}-\mathrm{SiO}_{2}-\mathrm{Na}_{2} \mathrm{O}$ from 7 to 35 kbar. J Petrol 35: 329-359

Ware NG (1991) Combined energy-dispersive-wavelength-dispersive quantitative electron microprobe analysis. X-ray Spectrometry 20: 73-79

White RS, McKenzie D, O’Nions RK (1992) Oceanic crustal thickness from seismic measurements and rare earth element inversions. J Geophys Res 97: 19683-19715 
Witt-Eickschen G, Seck HA (1991) Solubility of $\mathrm{Ca}$ and Al in orthopyroxene from spinel peridotite: an improved version of an empirical geothermometer. Contrib Mineral Petrol 106: 431-439

Wood BJ, Banno S (1973) Garnet-orthopyroxene and orthopyroxene-clinopyroxene relationships in simple and complex systems. Contrib Mineral Petrol 42: 109-124

Wood BJ, Blundy JD (1997) A predictive model for rare earth element partitioning between clinopyroxene and anhydrous silicate melt. Contrib Mineral Petrol 129: 166-181

Wood BJ, Henderson CMB (1978) Compositions and unit-cell parameters of synthetic non-stoichiometric tschermakitic clinopyroxenes. Am Mineral 63: 66-72
Wood BJ, Holloway JR (1984) A thermodynamic model for subsolidus equilibria in the system $\mathrm{CaO}-\mathrm{MgO}-\mathrm{Al}_{2} \mathrm{O}_{3}-\mathrm{SiO}_{2}$. Geochim Cosmochim Acta 48: 159-176

Wood BJ, Kirkpatrick RJ, Montez B (1986) Order-disorder phenomena in $\mathrm{MgAl}_{2} \mathrm{O}_{4}$ spinel. Am Mineral 71: 999-1006

Wood BJ, Blundy JD, Robinson JAC (1998) Crystal chemical constraints on the partitioning of U-series elements during partial melting. Mineral Mag 62A: 1664

Wood DA (1979) A variably veined suboceanic upper mantle genetic significance for mid-ocean ridge basalts from geochemical evidence. Geology 7: 499-503

Woodland AB, Droop G, O'Neill HStC (1995) Almandine-rich garnet from near Collobiières, southern France, and its petrological significance. Eur J Mineral 7: 187-194 